\title{
Investigation of the Association of Interleukin-21 and Macroprolactin Levels with Anti-thyroid Antibodies in Patients with Hashimoto's Thyroiditis
}



\begin{abstract}
Aim: Hashimoto's thyroiditis is part of the spectrum of autoimmune thyroid diseases characterized by the destruction of thyroid cells by antibody-mediated immune processes. Although there are some studies about the association of macroprolactinaemia and interleukin-21 (IL-21) levels with other autoimmune diseases, few studies have been found in association with the Hashimoto's thyroiditis in the literature. In this study, we aimed to see if there is any association between IL-21 and macroprolactin levels with antithyroid antibodies.

Subjects and Method: The study included 70 patients with Hashimoto's thyroiditis as the study group and 48 healthy volunteers as the control group. Interleukin-21, prolactin, free thyroxine, thyroid-stimulating hormone (TSH), antibodies against thyroglobulin (TG) and anti-thyroid peroxidase (anti-TPO) were determined in all participants. The presence of macroprolactinaemia was manifested by a polyethylene glycol precipitation method.

Results: There was no significant difference between the study and the control groups for free triiodothyronine (T3), free thyroxine (T4), prolactin and macroprolactin levels. We could not find any relationship between prolactin and macroprolactin levels with anti-TPO and anti-thyroglobulin (anti-TG) levels. Although IL-21 levels of the control group were significantly higher than the study group, there was also no correlation between IL-21 and anti-TPO and anti-TG levels.

Conclusion: Our results showed that neither macroprolactin nor prolactin levels have any relationship with anti-thyroid antibodies. Contrary to other studies, IL-21 levels of the control group were higher than the study group. We think that should be done with larger groups to better understand if there was any relationship of IL-21 and macroprolactin levels with Hashimoto's thyroiditis.
\end{abstract}

Keywords: Anti-thyroglobulin, anti-thyroid peroxidase, Hashimoto's thyroiditis, interleukin-21, Macroprolactin

\section{Investigación de la Asociación de los Uiveles de Interleucina-21 y Macroprolactina con los Anticuerpos Antitiroideos en Pacientes con Tiroiditis de Hashimoto}

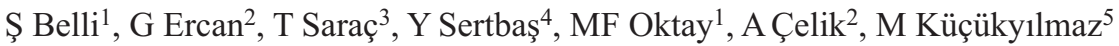

\begin{abstract}
RESUMEN
Objetivo: La tiroiditis de Hashimoto es parte del espectro de enfermedades autoinmunes de la tiroides, caracterizadas por la destrucción de las células tiroideas por procesos inmunes mediados por anticuerpos. Aunque existen algunos estudios sobre la asociación de la macroprolactinemia y los niveles de interleucina-21 (IL-21) con otras enfermedades autoinmunes, se han encontrado pocos estudios de la tiroiditis de Hashimoto en la literatura. En este estudio buscamos ver si existe alguna asociación de los niveles de IL-21 y macroprolactina con los anticuerpos antitiroideos.

Sujetos y método: El estudio incluyó 70 pacientes con tiroiditis de Hashimoto como grupo de estudio, y 48 voluntarios sanos como grupo de control. La interleucina-21, la prolactina, la tiroxina libre, la hormona estimulante de la tiroides (HET), los anticuerpos contra la tiroglobulina (TG), y la peroxidasa antitiroidea (anti-POT) se determinaron en todos los participantes. La presencia de macropro-lactinemia fue detectada por un método de precipitación de glicol de polietileno.
\end{abstract}

From: ${ }^{1}$ Ear Nose Throat Disorders Clinic, ${ }^{2}$ General Surgery Clinic, ${ }^{3}$ Biochemistry, Bagcilar Education and Research Hospital, Istanbul, Turkey, ${ }^{4}$ Internal Medicine, Uskudar State Hospital, Istanbul, Turkey and ${ }^{5}$ General Surgery, Istanbul Education and Research Hospital, Istanbul, Turkey.
Correspondence: Dr S Belli, Bagcilar Education and Research Hospital, Ear Nose Throat Disorders Clinic, Istanbul, Turkey. Email: drseydabelli@ gmail.com 
Resultados: No hubo diferencias significativas entre los grupos de estudio y control con relación a los niveles de triyodotironina libre (T3), tiroxina libre (T4), prolactina, y macroprolactina. No pudimos encontrar ninguna relación de los niveles de prolactina y macroprolactina con los niveles de anti-POT y anti-tiroglobulina (anti-TG). Aunque los niveles de IL-21 del grupo de control fueron significa-tivamente mayores que los del grupo de estudio, no se halló tampoco correlación de los niveles de IL-21 con los niveles de anti-TG y anti-POT.

Conclusión: Nuestros resultados mostraron que ni los niveles de macroprolactina ni los niveles de prolactina guardan relación alguna con los anticuerpos antitiroideos. Contrariamente a lo expuesto en otros estudios, los niveles de IL-21 del grupo control fueron mayores que los del grupo de estudio. Pensamos que el estudio debe hacerse con grupos más grandes para entender si hubo alguna relación de los niveles de IL-21 y la macroprolactina con la tiroiditis de Hashimoto.

Palabras claves: Anti-tiroglobulina, peroxidasa antitiroidea, tiroiditis de Hashimoto, interleucina-21, macroprolactina

West Indian Med J 2017; 66 (1): 125

\section{INTRODUCTION}

Autoimmune diseases encompass a wide spectrum of disorders from an organ specific to multisystemic involvement. Hashimoto thyroiditis (HT) is a part of the spectrum of autoimmune thyroid diseases (AITDs) and is characterized by the destruction of thyroid cells by various cells and antibody mediated immune processes. Hashimoto thyroiditis association with systemic autoimmune diseases including systemic lupus erythematosus, Sjögren syndrome, systemic sclerosis and rheumatoid arthritis has been described (1).

Prolactin (PRL), also known as a luteotropic hormone or luteotropin, is a hormone produced by the pituitary gland, with a role in stimulation of lactation. However, it also has many other functions with over 300 separate actions, including essential roles in the maintenance of the immune system (2). Prolactin specifically interferes with $\beta$-cells and increases the production of immunoglobulins, cytokines and autoantibodies (3). There are mainly three different forms of prolactin in regard to size, predominantly monomeric prolactin but also as small but variable amounts of 'big prolactin' and 'big big prolactin [macroprolactin] (4). The binding of prolactin to an immunoglobulin forms macroprolactin and is usually formed by IgG antibody. Macroprolactinaemia has been found to be associated with different autoimmune diseases such as systemic lupus erythematosus and rheumatoid arthritis in different studies (5-6).

Cytokines are a broad category of small proteins that are important in cell signalling. They play a central role in inflammatory and immune responses. Interleukins are a group of cytokines located at chromosome 4q27, and they were recently shown to be associated with autoimmune diseases such as coeliac disease, Type 1 diabetes, Grave's disease (GD) and rheumatoid arthritis (7).

Although there are some studies about the association of macroprolactinaemia and IL-21 levels with other autoimmune diseases, there are few about the HT in the literature. In this study, we aimed to see if there is any association between HT with IL-21 and macroprolactin levels.

\section{SUBJECTS AND METHODS}

\section{Subjects}

We have taken 70 patients with Hashimoto's thyroiditis as the study group and 48 healthy volunteers as the control group. Autoimmune thyroid disease was defined as raised titre of at least one of the anti-thyroid antibodies [anti-thyroid peroxidase (anti-TPO), anti-thyroglobulin (anti-TG)]. Patients with HT admitted to the clinic for the first time, were selected as the study group. Healthy volunteers from the same region of Istanbul without a family history of Hashimoto's thyroiditis or other autoimmune diseases served as the control group. None of the groups was taking any drug that could influence PRL and thyroid hormone levels.

Informed consent was obtained from all participants, and the study was approved by the Ethics Committee of Bagcilar Education and Research Hospital.

\section{Measurement of serum macroprolactin concentration}

The level of prolactin was measured in both Hashimoto's thyroiditis and the healthy volunteers, groups. The presence of macroprolactinaemia was manifested by polyethylene glycol (PEG) precipitation method. This method involves precipitation of monomeric Prl-IgG complex with $25 \%$ polyethylene glycol. The concentration of prolactin is assessed before and after polyethylene glycol precipitation. Significant macroprolactinaemia was said to be present, where the PRL recovery in the second sample was less than $40 \%$. According to some authors, $40-60 \%$ recovery is considered to represent, the so-called grey zone. We have deemed to be over $60 \%$ of the macroprolactinaemia.

\section{Measurement of serum IL-21 concentration}

The concentration of IL-21 polypeptide in the different sera was determined with a commercially available ELISA kit (R\&D Systems Minneapolis, MN). The lower limit for IL-21 was considered $31 \mathrm{pg} / \mathrm{mL}$. 


\section{Statistics}

In this study, statistical analysis was made with Number Cruncher Statistical System (NCSS) — 2007, Statistical Software (Utah, USA). Data were evaluated by descriptive statistical methods (mean, standard deviation, median, interquartile range) as well as the normal distribution of the variables binary comparisons of groups and Mann-Whitney$\mathrm{U}$ test normally distributed variables, binary comparisons of groups and independent $t$-test, qualitative comparisons of data in the Chi-squared test of variables to determine their relationship with each other, Spearman correlation test was used. Differences were considered as significant when $p<$ 0.05 .

\section{RESULTS}

There were no significant age and gender difference between study group and the control group $[p=0.102, p=0.325]$ (Table $1)$.

Table 1: Standard distribution of the working groups

\begin{tabular}{lccl}
\hline & Age & Female & Male \\
\hline Study group & $37.94 \pm 10.07$ & $65(\% 92.9)$ & $5(\% 7.1)$ \\
Control group & $34.9 \pm 8.78$ & $42(\% 87.5)$ & $6(\% 12.50)$ \\
& $p=0.102$ & $p=0.325$ & \\
\hline
\end{tabular}

Thyroid-stimulating hormone levels of the study group were significantly higher than the control group $(p=0.0001)$. All in the study group, anti-TPO and anti-TG levels were highly elevated and significantly higher than the control group $(p=0.0001$ and $p=0.0001)$. There were no significant differences between the study and the control groups for T3, T4, Prl, macroprolactin levels (Table 2.)

Table 2: Comparison of the laboratory results of control and study groups

\begin{tabular}{lccl}
\hline & Study group & Control group & $\boldsymbol{p}$-value \\
\hline TSH & $3.12 \pm 2.36$ & $1.70 \pm 0.91$ & 0.0001 \\
fT3 & $2.97 \pm 0.39$ & $3.12 \pm 0.44$ & 0.07 \\
fT4 & & & 0.830 \\
Anti-TPO & $1.08 \pm 0.23$ & $1.07 \pm 0.14$ & 0.0001 \\
Anti-TG & $719.48 \pm 571.01$ & $46.76 \pm 8.51$ & 0.0001 \\
PRL & $245.52 \pm 500.7$ & $15.48 \pm 1.3$ & 0.670 \\
MPR & $11.62 \pm 9.41$ & $9.81 \pm 5.65$ & 0.556 \\
Macroprolactinemia & $5.86 \pm 7.19$ & $4.62 \pm 2.2$ & 0.1889 \\
IL-21 & $5 / 65$ & $7 / 41$ & 0.004 \\
& $561.59 \pm 500.71$ & $757.38 \pm 550.53$ & \\
\hline
\end{tabular}

TSH: thyroid-stimulating hormone; fT3: free triiodothyronine; fT4: free thyroxine; Anti-TPO: anti-thyroid peroxidase; Anti-TG: anti-thyroglobulin; PRL: prolactin; IL-21: interleukin-21

We could not find any relationship between PRL and macroprolactin levels with anti-TPO and anti-TG (anti-thyroglobulin) levels (Table 3). Interleukin-21 levels in the control group were significantly higher than the study group ( $p=$ $0.004)$. There was also no correlation between IL-21 and antiTPO and anti-TG levels (Table 3).
Table 3: Relationship of prolactin; macroprolactin and interleukin-21 levels with anti-thyroid antibodies

\begin{tabular}{rlrrr}
\hline & & PRL & MPRL & IL-21 \\
\hline \multirow{2}{*}{ TPO } & $\mathbf{r}$ & -0.041 & -0.139 & -0.172 \\
& $\mathbf{p}$ & 0.659 & 0.133 & 0.062 \\
aTG & $\mathbf{r}$ & 0.039 & -0.026 & -0.172 \\
& $\mathbf{p}$ & 0.675 & 0.782 & 0.063 \\
\hline
\end{tabular}

TPO: thyroid peroxidase; PRL: prolactin; MPRL: macroprolactin; IL-21: interleukin-21

\section{DISCUSSION}

Hashimoto's is the most common thyroid-specific autoimmune disease in society. Its association with systemic autoimmune diseases has been described, including systemic lupus erythematosus, Sjögren syndrome, systemic sclerosis and rheumatoid arthritis (1). In this study, we compared the serum levels of IL-21 and macroprolactin in patients with HT and healthy volunteers to see if there is any association with thyroid antibodies.

Animal and clinical studies demonstrated the dysregulations of IL-21 in autoimmune diseases $(8,9)$. For example, Scofield in his manuscript mentioned that serum IL-21 levels in patients with primary Sjögren's syndrome has a positive correlation with the serum levels of gammaglobulin (10). It is clear that B cells are hyperactivated in patients with Sjogren's syndrome. Interleukin-21 promotes the proliferation of B cells, resulting in differentiation into plasma cells, which produce immunoglobulins, especially IgG1. The dysregulation of IL- 21 plays a role in multiple immune-mediated diseases, including; systemic lupus erythematosus (SLE), psoriasis, rheumatoid arthritis (RA) and other chronic inflammatory diseases (8, 9, 11). Jia also reported increased serum IL-21 level in a patient with primary Graves disease (7).

In many publications, patients with HT also have been reported to be together with other autoimmune diseases such as SLE, Sjögren's syndrome, rheumatoid arthritis and psoriasis. Gottenberg et al compared the serum cytokines for a correlation with the diagnosis, activity and severity of rheumatoid arthritis. Only serum IL-6 concentration was greater in RA than in undifferentiated arthritis, with an increase in serum IL6 and IL-21 levels associated with markers of B cell activation (12). Gene expression of IL-1, IL-2, IL-4, IL-6, IL-8, IL-10, IL-12, IL-13, IL-14, IL-15, IL-16, IFN $\gamma$, TNF $\alpha$ and a number of chemokines have been shown in both GD and HT tissue samples (13). Although some studies, using quantitative techniques, have shown a Th1 response in the HT and a Th2 response in GD, generally a mixed Th1 and Th2 pattern have been found in the samples analysed (14). In our study, there was a significant difference between the HT and the control groups for IL-21 levels but not as expected. Unlike other studies, we found that IL-21 levels were higher in the control group rather than the study group.

Prolactin circulates in several different molecular forms and binding of it to immunoglobulins form the macroprolactin. 
Systematic lupus erythematosus and RA as autoimmune diseases with an increased prevalence of serum autoantibodies were associated with macroprolactinaemia $(5,6)$. There are also some studies showing significantly higher prolactin levels in HT patients rather than controls $(15,16)$. However, there are also studies showing different results as a decreased bioactivity of circulating prolactin in patients with rheumatoid arthritis (17). Krzysztof and his colleagues also found no evidence that autoimmune thyroid diseases have an association with raised prevalence of macroprolactinaemia (18). We also could not find any association between either hyperprolactinaemia and macroprolactinaemia with the HT.

According to our results, neither macroprolactin nor prolactin levels have any association with HT. In contrast, the other studies, IL-21 levels of the control group were higher than the HT group. We think that studies with larger groups should be done to better understand if there is any relationship of IL-21 and macroprolactine levels with the HT.

\section{REFERENCES}

1. Biró E, Szekanecz Z, Czirják L, Dankó K, Kiss E, Szabó NA et al. Association of systemic and thyroid autoimmune diseases. Clin Rheumatol 2006; 25: 240-5.

2. Bole-Feysot C, Goffin V, Edery M, Binart N, Kelly PA. Prolactin (PRL) and its receptor: actions, signal transduction pathways and phenotypes observed in PRL receptor knockout mice. Endocr Rev 1998; 19: 225-68.

3. Shelly S, Boaz M, Orbach H. Prolactin and autoimmunity. Autoimmun Rev 2012; 11: 565-70.

4. Hattori N. Macroprolactinemia: a new cause of hyperprolactinemia. J Pharmacol Sci 2003; 92: 171-7.

5. Orbach H, Zandman-Goddard G, Boaz M, Agmon-Levin N, Amital H, Szekanecz $\mathrm{Z}$ et al. Prolactin and autoimmunity: hyperprolactinemia correlates with serositis and anemia in SLE patients. Clin Rev Allergy Immunol 2012; 42: 189-98.

6. Adachi T, Hattori N, Ishihara T, Iida H, Saito T, Miyashima S et al. Possible involvement of matrix metalloproteinase-3 in the pathogenesis of macroprolactinaemia in some patients with rheumatoid arthritis. Eur $\mathrm{J}$ Endocrinol 2013; 169: 203-9.
7. Jia HY, Zhang ZG, Gu XJ, Guo T, Cui B, Ning G et al. Association between interleukin 21 and Graves' disease. Genet Mol Res 2011; 10: 3338 46.

8. Bubier JA, Sproule TJ, Foreman O, Spolski R, Shaffer DJ, Morse HC 3rd et.al. A critical role for IL-21 receptor signaling in the pathogenesis of systemic lupus erythematosus in BXSB-Yaamice. Proc Natl Acad Sci USA 2009; 106: 1518-23.

9. Li J, Shen W, Kong K, Liu Z. Interleukin-21 induces T-cell activation and proinflammatory cytokine secretion in rheumatoid arthritis. Scand $\mathrm{J}$ Immunol 2006; 64: 515-22.

10. Scofield RH. IL-21 and Sjögren's syndrome. Arthritis Res Ther 2011; 13: 137.

11. Yuan SL, Jiang L, Zhang XL, Li SF, Duan HM, Wang XF. Serum IL-21 level in patients with primary Sjogren's syndrome and clinical significance of IL-21. Xi Bao Yu Fen Zi Mian Yi Xue Za Zhi 2007; 23: 124-6.

12. Gottenberg JE, Dayer JM, Lukas C, Ducot B, Chiocchia G, Cantagrel A et al. Serum IL-6 and IL-21 are associated with markers of Bcell activation and structural progression in early rheumatoid arthritis: results from the ESPOIR cohort. Ann Rheum Dis 2012; 71: 1243-8.

13. Ajjan RA, Watson PF, Weetman AP. Cytokines and thyroid function. Adv Neuroimmuno 1996; 6: 359-86.

14. Heuer M, Aust G, Ode-Hakim S, Scherbaum WA. Different cytokine mRNA profile in Graves' disease, Hashimoto's thyroiditis, and non autoimmune thyroid disorders determined by quantitative reverse transcriptase polymerase chain reaction (RT-PCR). Thyroid 1996; 6: 97-105.

15. Pelkonen R, Salmi J, Lamberg BA. Interrelationship between TSH- and prolactin secretion in patients with prolactinoma and autoimmune thyroiditis. Acta Endocrinol (Copenh) 1982; 100: 184-8.

16. Legakis I, Petroyianni V, Saramantis A, Tolis G. Elevated prolactin to cortisol ratio and polyclonal autoimmune activation in Hashimoto's thyroiditis.Horm Metab Res 2001; 33: 585-9.

17. Berczi I, Cosby H, Hunter T, Baragar F, McNeilly AS, Friesen HG. Decreased bioactivity of circulating prolactin in patients with rheumatoid arthritis. Br J Rheumatol 1987; 26: 433-6.

18. Lewandowski KC, Gąsior-Perczak D, Kowalska A, Lewiński A. Prevalence of macroprolactinaemia in regularly menstruating women with nontoxic goitre or autoimmune thyroid disease. Thyroid Res 2012; 5: 20. 